\section{Evaluation of tissue in repair with natural latex and / or hyaluronic acid in surgical bone defects}

\author{
João Paulo Mardegan Issa@ ${ }^{1}$, Otavio Marino dos Santos Neto@ ${ }^{2}$, Ana \\ Paula Macedo ${ }^{2}$, Miliane Gonçalves Gonzaga ${ }^{1}$, Yamba Carla Lara \\ Pereira ${ }^{1}$, Sara Feldman $0^{3}$.
}

\begin{abstract}
This study evaluated the bone repair in surgical defects of rats treated with hyaluronic acid (HA) associated or not with Hevea brasiliensis fraction protein $(\mathrm{F}-1)$. Bone defect were created in 15 albino Wistar rats divided into 3 groups ( $n=5)$ : Control group (1) - blood clot; HA group (2) - $0.5 \%$ hyaluronic acid; HAF1 group (3) - $0.1 \% \mathrm{~F}-1$ protein fraction dissolved in $0.5 \%$ hyaluronic acid. After 4 weeks, the animals were euthanized and the bone repair was evaluated through histomorphometric analysis, zymography and immunohistochemistry. The neoformed bone area did not show a significant difference $(p=0.757)$, but there was a tendency for bone trabeculation to increase in the groups HA and HAF1. For immunohistochemically analysis, there was a difference in vascular endothelial growth factor (VEGF) labeling $(\mathrm{p}=0.023)$, being higher in the groups HA and HAF1 than the control group. No significant difference in bone sialoprotein (BSP) $(\mathrm{p}=0.681)$, osteocalcin $(p=0.954)$, however, significant difference in platelet endothelial cell adhesion molecule-1 $(\mathrm{CD}-31)(\mathrm{p}=0.040)$, with HAF1 group being significantly lower than the control. For zymographic analysis, there was no significant difference for metalloproteinase-2 (MMP-2) $(\mathrm{p}=0.068)$, but there was a tendency to increase MMP-2 in the HA group. Despite the influence on angiogenic factors and the apparent tendency for greater trabeculation in the HA and HAF1 groups, there was no significant difference in the area of newly formed bone tissue in the analyzed period.
\end{abstract}

\author{
${ }^{1}$ São Paulo University (USP), School of \\ Dentistry, Department of Basic and Oral \\ Biology, Ribeirão Preto, SP, Brazil.
}

Correspondence: João Paulo Mardegan Issa telephone: (55) 16- 33153000 e-mail: jpmissa@forp.usp.br address: Faculdade de Odontologia de Ribeirão Preto - USP Avenida do Café, s/n - Campus da USP Zip code: 14040-904, Ribeirão Preto, SP, Brazil

Key Words: Bone repair, bone defects, Hevea brasiliensis, hyaluronic acid, biomaterials.

\title{
Introduction
}

The bone repair has aroused great interest in experimental research, since bone defects, congenital or caused by diseases, trauma or surgeries, do not heal spontaneously, being a challenge for orthopedic and dental practice(1). Several strategies have been developed to promote bone regeneration, such as the use of bone grafts, implants of various types, guided tissue regeneration barrier, growth factors, and especially bone morphogenetic proteins - BMPs (2-4). Many of these materials have shown only limited efficacy for bone repair, and some have specific disadvantages $(1,5-7)$

The natural latex, extracted from Hevea brasiliensis, has been highlighted as a new biomaterial since it has angiogenic potential and stimulates tissue repair(8-14). The use of natural biomembrane developed derived from Hevea brasiliensis latex or, protein fraction obtained by lyophilization process induced the formation of new vessels(15). The biomembrane used to accelerate the repair of ocular conjunctiva in rabbits promoted a greater number of new blood vessels and reduced the risk of infection(16).

On the bone repair, the natural latex integrated causing better healing and reported bone growth without any evidence of hypersensitivity or inflammation. Furthermore, this material is promising because it has elasticity, flexibility, low cost, biocompatibility and ability to promote and accelerate angiogenesis(6,17). In addition, new technologies have been developed to improve the performance of natural latex, for example, the creation of biomembranes with better cell adhesion $(6,18)$.

In addition to the angiogenic protein fraction obtained from latex (F-1), the hyaluronic acid has also aroused interest in the application of tissue repair, for being able to promote migration and cell division of fibroblasts(19). The hydrogel has affinity for water behave as a matrix for the gradual release of other biomaterials that favor bone formation and participate directly in this process performing several functions(20).

The evident neoangiogenic action of the F-1 protein fraction needs to be addressed in more studies, involving experimental animals, suitable carriers and different methodologies, because the need 
for less expensive material with adequate biological properties is a constant challenge in the regenerative science. The present research had the aim to evaluate the bone healing process in calvarial bone defects in Wistar rats treated with hyaluronic acid gel associated or not with the protein fraction extracted from Hevea brasiliensis, through quantitative histomorphometric analysis, and zymography and immunohistochemistry studies.

\section{Material and Methods}

\section{Animals}

Fifteen male Wistar rats, 45 days old, with approximately 250 grams, were used, from the Central Bioterium of the Campus of Ribeirão Preto, USP. All the procedures involved in this study follow the ethical norms and were approved at Ethics Committee on Animal Experiments of Ribeirão Preto Medical School, (protocol 13178535), in confirmation to all the methods and guidelines of CONCEA (National guideline of animal use on experimentation from Brazil), and followed the ARRIVE Guidelines(21). These animals were randomly divided into 3 groups (five animals on each) with a waiting period until the sacrifice of 4 weeks according to the filling of the bone defect: control blood clot; HA - $0.5 \%$ hyaluronic acid in buffered saline; HAF1-0.1\% F-1 dissolved in $0.5 \%$ hyaluronic acid in buffered saline. From each animal, one bone sample was used for the zymographic analysis and another sample for histomorphometric and immunohistochemical analyses.

\section{Formulations}

A $0.1 \mathrm{M}(\mathrm{pH} 7.35)$ sodium phosphate-buffered saline and $0.5 \%$ hyaluronic acid was prepared for group HA and a $0.1 \mathrm{M}(\mathrm{pH} 7.35)$ sodium phosphate-buffered saline, $0.5 \%$ hyaluronic acid and $0.1 \%$ the fraction (F-1) of Hevea brasiliensis was prepared for group HAF1. Natural latex is extracted from rubber tree Hevea brasiliensis by the traditional incision process. The drained ammonia-containing liquid for coagulation is then diluted in $2.2 \%$ acetic acid in a 1:2 ratio. After the period, protein whey is obtained, which undergoes a chromatographic purification process and is diluted with water in 1:1 ratio and the $\mathrm{pH}$ adjusted to 9.0 with $5 \mathrm{M} \mathrm{NaOH}$. The chromatography process was performed and the material was obtained at the first peak called F1. The application of the protein extracted from pure Hevea brasiliensis in the surgical area was not considered in this study, due to its dispersion of the site where it is applied, as observed after the pilot study. The Laboratory of Biochemistry and Immunology of FMRP-USP supplied extracted protein fraction 1 of Hevea brasiliensis and hyaluronic acid (Nikkol, Japan) in gel form.

\section{Surgical Procedures and Local Treatment}

The animals were anesthetized with the anesthetic solution in the proportion of $75 \mathrm{mg} / \mathrm{kg}$ of Ketamine Dopalen ${ }^{\circledR}$ and $5 \mathrm{mg} / \mathrm{kg}$ of Xylazine (Agribrands, Campinas, Brazil), injected intraperitoneally. Sterile gauze soaked in $0.9 \%$ saline was also applied to the eyes of the animals during surgery to prevent dryness of the corneas. A sagittal incision of approximately $1 \mathrm{~cm}$ in length was performed in the central region of the calvaria and the subcutaneous tissue, the musculature and the periosteum were removed to expose the bone region.

Two bone defects were created, one in the right parietal lobe region and the other in the left lobe parietal region symmetrically. For this, a surgical drill with $6 \mathrm{~mm}$ external diameter and $5 \mathrm{~mm}$ internal diameter was used, an electric motor for implants and irrigation with constant and abundant saline solution $0.9 \%$.

The bone defects were filled according to the animal's group using a micropipette ( $20 \mu \mathrm{L}$ HA or $20 \mu \mathrm{L} \mathrm{HAF} 1$ ) and, after surgery, the tissues were repositioned and the skin was sutured with silk thread 4.0 (Ethicon, Johnson \& Johnson, Sao Jose dos Campos, SP, Brazil). Then, each animal received a dose of 25,000 IU / kg of the penicillin + steptomycin (Fort Dodge ${ }^{\circledR}$, Campinas, SP, Brazil). After 4 weeks of creation of the bone defects, the animals were submitted to euthanasia to obtain the samples of interest.

\section{Sample}

The area of bone defect was removed with a safety margin, maintaining $2 \mathrm{~mm}$ around each bone defect. Twenty samples was obtained, where staining 10 glasses $(1,2,7,8,13,14,19,20)$ destined to histomorphometric and histological analysis and the others were keeped for imuhistochemical 
procedures. The samples used in the zymography were placed in liquid nitrogen and stored at $-80{ }^{\circ} \mathrm{C}$.

\section{Histological and Histomorphometric analysis}

The samples were fixed for 24 hours in $4 \%$ formaldehyde in $0.1 \mathrm{M}$ phosphate buffer solution ( $\mathrm{pH}$ 7.4), decalcified in 0.5M EDTA (ethylene diamine tetraacetic acid) for 20 days and submitted to conventional histological treatment to be included in paraffin. The $5 \mu \mathrm{m}$ semi-serial sections obtained from the samples were stained with a Masson trichrome, counting 10 samples. After obtaining the slides, bone neoformation, absence of inflammatory infiltrate and formation of connective tissue were evaluated by histological analysis.

In order to quantify the mineralized bone tissue and perform histological analysis, three photomicrographs on each slide were selected for digital capture, in 5X magnification, including the bone defect. The glasses was analyzed by Axio Imager Z2 $®$ light microscope coupled to a digital camera (Zeiss, Oberkochen, BW, Germany). The areas were photographed and the images captured and analyzed by semi - automatic technique, by AxionVision ${ }^{\circledR}$ software (Zeiss, Germany). The panoramic images of the defect images were obtained with the $5 \times$ objective, being collected images with $3.5 \times 2.5$ $\mathrm{mm}$. Thus, using the "free hands" tool, area of newly formed bone was calculated in $\mu \mathrm{m}^{2}$. The data obtained were arranged and statistical tests were applied.

\section{Immunohistochemical analysis}

Immunoblotting of angiogenic and osteogenic factors were performed: VEGF (mouse, 1:100, SC-7269, Santa Cruz Biotechnology), BSP (rabbit, 1:100; ab 52128, ABCAM), Osteocalcin (goat, 1:100, SC-18319, Santa Cruz Biotechnology), CD - 31 (goat, 1:180, SC-1506, Santa Cruz Biotechnology) and EnVision + System - HRP - DAB (Dako-K4011). Post-blocking of the endogenous peroxidase with hydrogen peroxide (10 volumes) of nonspecific bindings with PBS / 2\% BSA for one hour each, the sections were dipped in citrate buffer solution $\mathrm{pH} 6.0$ in a water bath to Antigen recovery. After cooling and washing in PBS, the samples were incubated with the primary antibodies for eighteen hours at $4-8{ }^{\circ} \mathrm{C}$. The sections were then washed in PBS and incubated at $4-8{ }^{\circ} \mathrm{C}$ for 3 hours with the secondary antibody. The reaction was developed with diaminobenzidine solution $(0.5 \mathrm{mg} / \mathrm{mL})$ and liquid hydrogen peroxide $(0.005 \mathrm{~mL} / 100 \mathrm{~mL})$ in PBS for 10 minutes. The sections were washed in PBS, counterstained with Mayer's hematoxylin, dehydrated, diaphanized and covered with coverslips using Entellan (Merck). The analysis of the immunostaining was performed with the aid of Axion Vision Zeiss (Germany) software where the browning intensities in each field were marked(22). As a positive control, a rat femur cut (paraffinized stock material) was used, which presented bone wound repair. The negative control consisted of suppressing the use of primary antibodies.

The immunostaining pattern was assessed using scores, adapting the criteria established by Faria et al. (2008)(23): Score $0=$ absence of immunostaining; Score $1=$ low pattern of immunostaining; Score $2=$ moderate pattern of immunostaining; Score $3=$ high standard of immunostaining.

\section{levels}

\section{Zymography on 12\% sds-polyacrylamide gel with gelatin substrate to determine MMP-2}

The procedures for verifying the activity of MMP-2 and -9 followed the protocol of Marqueti et al. (2008)(24), which was adapted for this study. Each group of animals was analyzed together. The skullcap being repaired was removed, cleaned and macerated with liquid nitrogen. The macerated bone sample was incubated in extraction buffer $(300 \mu l$ for each $0.1 \mathrm{~g}$ sample) containing $10 \mathrm{mM} \mathrm{CaCl} 2,50 \mathrm{mM}$ Tris- $\mathrm{HCl} \mathrm{pH} 7.4,0.1 \%$ Brij, $0.15 \mathrm{M} \mathrm{NaCl}, 1 \mathrm{mM}$ Phe (1 : 10-orthophenanthroline), $1 \mathrm{mM}$ phenylmethanesulfonylfluoridate and $1 \mathrm{Mm}$ N-ethylmaleimide. The samples were stored on ice in a refrigerator for 20 hours and then centrifuged at 10,000g for 15 minutes.

Protein content was measured using the Bradford method(25). The samples were then diluted 1:1 with sample buffer (final concentration: $2 \%$ SDS-sodium dodecyl sulfate, $125 \mathrm{mM}$ Tris-HCl $\mathrm{pH} 6.8,10 \%$ glycerol and $0.001 \%$ bromophenol blue) and $40 \mathrm{mg}$ of total protein was applied to each well in a SDSpolyacrylamide $12 \%$ gelatinized copolymerized gelatin $(0.1 \%)$ as the substrate, carried at $4 \mathrm{oC}$ using a constant current of $35 \mathrm{~mA}$ at $90 \mathrm{~V}$ for approximately $5 \mathrm{~h}$. The protein molecular weight marker (PageRuler Plus Prestained Protein Ladder, Fermentas, Ontario, Canada) was used in the gel.

After completion of electrophoresis, the gel was incubated for 1 hour at room temperature in $2 \%$ Triton X-100 solution and then incubated for 16 hours at $37{ }^{\circ} \mathrm{C}$ in Tris- $\mathrm{HCl}$ buffer $\mathrm{pH} 7.4$ containing 10 $\mathrm{mmol} / \mathrm{L} \mathrm{CaCl}_{2}$. The gels were stained with $0.05 \%$ CoomassieG- 250 brightening blue and decolorized with $30 \%$ methanol and 10\% acetic acid. The measurement of gelatinolytic activity was done through 
uncolored bands on Coomassie-stained gelatin. Enzymatic activity was analyzed by densitometry using the Kodak Electrophoresis Documentation and Analysis System 290 (Kodak, Rochester, NY, USA). The gelatinolytic activity was normalized with an internal standard (fetal bovine serum), allowing full analysis and comparison. MMP-2 isoforms were identified in the 72 and $64 \mathrm{kDa}$ bands. Negative control were extraction buffer containing $10 \mathrm{mM} \mathrm{CaCl} 2,50 \mathrm{mM}$ Tris- $\mathrm{HCl}, 1 \mathrm{mM}$ Phe (1,10 orthophenanthroline), $1 \mathrm{mM}$ phenylmethanesulfonylfluoride (PMSF) and $1 \mathrm{mM}$-ethylmaleimide.

\section{Statistical analysis}

Statistical analyses were performed by IBM - SPSS $^{\circledR}$ Statistics 20.0 (IBM Corporation). A normality test was performed (Shapiro - Wilk) and, once the data adhered to the normal curve, a variance analysis (ANOVA) was performed and, when there was a significant difference, a Tukey post-test was performed. The significance level was set at $5 \%(\alpha=0.05)$.

\section{Results}

Figure 1 shows micrographs of the regions in which the bone neoformation was evaluated. In all groups, the descriptive histological analysis revealed that almost the entire bone defect was filled with repair tissue; and the newly formed bone tissue surrounded the edges of the bone defect, advancing towards its center. In the control group (Figure 1 - A, B), the presence of fibrous connective tissue rich in fibroblasts was apparently more significant than in the HA and HAF1 groups. The HA (Figure 1- C, D) and HAF1 groups (Figure 1- E, F) visually presented neoformed bone tissue with more mature features of structure than the control group, in addition to a tendency to trabeculation. Quantitative results are shown in Table 1 and Figure 2. In the histomorphometric analysis, neoformed bone area did not present a significant difference $(\mathrm{p}=0.757)$. According to immunohistochemical analysis, there was a difference for VEGF (Figure 3AI, A-II, A-III) labeling ( $\mathrm{p}=0.023)$, being higher in the HA and HAF1 groups concerning the control. There was no significant BSP difference $(\mathrm{p}=0.681)$ (Figure 3B-I,B-II,BIII). There was no significant difference in osteocalcin $(\mathrm{p}=0.954)$ (Figure 3C-I,C-II,C-III). There was a significant difference in CD-31 ( $\mathrm{p}=0.040)$, with HAF1 being significantly lower than the control (Figure 3D-I,D-II,D-III). Zymographic analysis showed no significant difference for MMP-2 ( $\mathrm{p}=0.068$ ) (Figure 2).

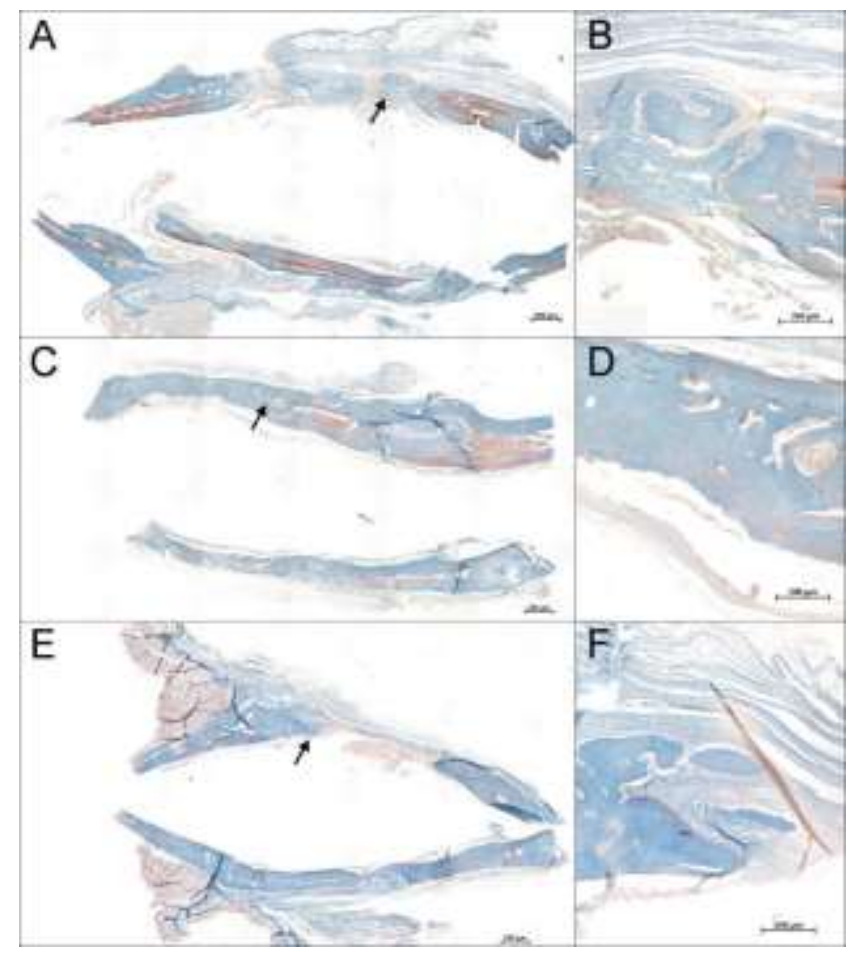

Figure 1. Micrographs of the regions of new bone formation: AB: Control; C-D: HA and E-F: HAF1. A-C-E represent panoramic photo with 6 fields in 5x objective; B-D-F region detail starting the new bone formation (10x of magnification-microscopy lens). 
Table 1. Mean (standard deviation) of the obtained results.

\begin{tabular}{lccr}
\hline & C & HA & HAF1 \\
\hline New bone area $\left(\mathrm{x} 10^{5} \mu \mathrm{m}^{2}\right)$ & $7.68(1.80)$ & $8.43(1.63)$ & $8.03(1.20)$ \\
MMP2 & $51.06(8.07)$ & $73.56(27.27)$ & $47.23(9.30)$ \\
VEGF $\left(\mathrm{x} 10^{3} \mu \mathrm{m}^{2}\right)$ & $0.88(0.26)^{\mathrm{A}}$ & $1.75(0.58)^{\mathrm{B}}$ & $1.67(0.51)^{\mathrm{B}}$ \\
BSP $\left(\mathrm{x} 10^{3} \mu \mathrm{m}^{2}\right)$ & $0.58(0.22)$ & $0.70(0.44)$ & $0.79(0.40)$ \\
Osteocalcin $\left(\mathrm{x} 10^{3} \mu \mathrm{m}^{2}\right)$ & $0.387(0.08)$ & $0.366(0.20)$ & $0.401(0.21)$ \\
CD31 $\left(\mathrm{x} 10^{3} \mu \mathrm{m}^{2}\right)$ & $3.132(1.36)^{\mathrm{A}}$ & $1.56(1.40)^{\mathrm{AB}}$ & $1.16(0.09)^{\mathrm{B}}$ \\
\hline
\end{tabular}

$\overline{\mathrm{AB}}$ Different letters show statistical difference between groups.
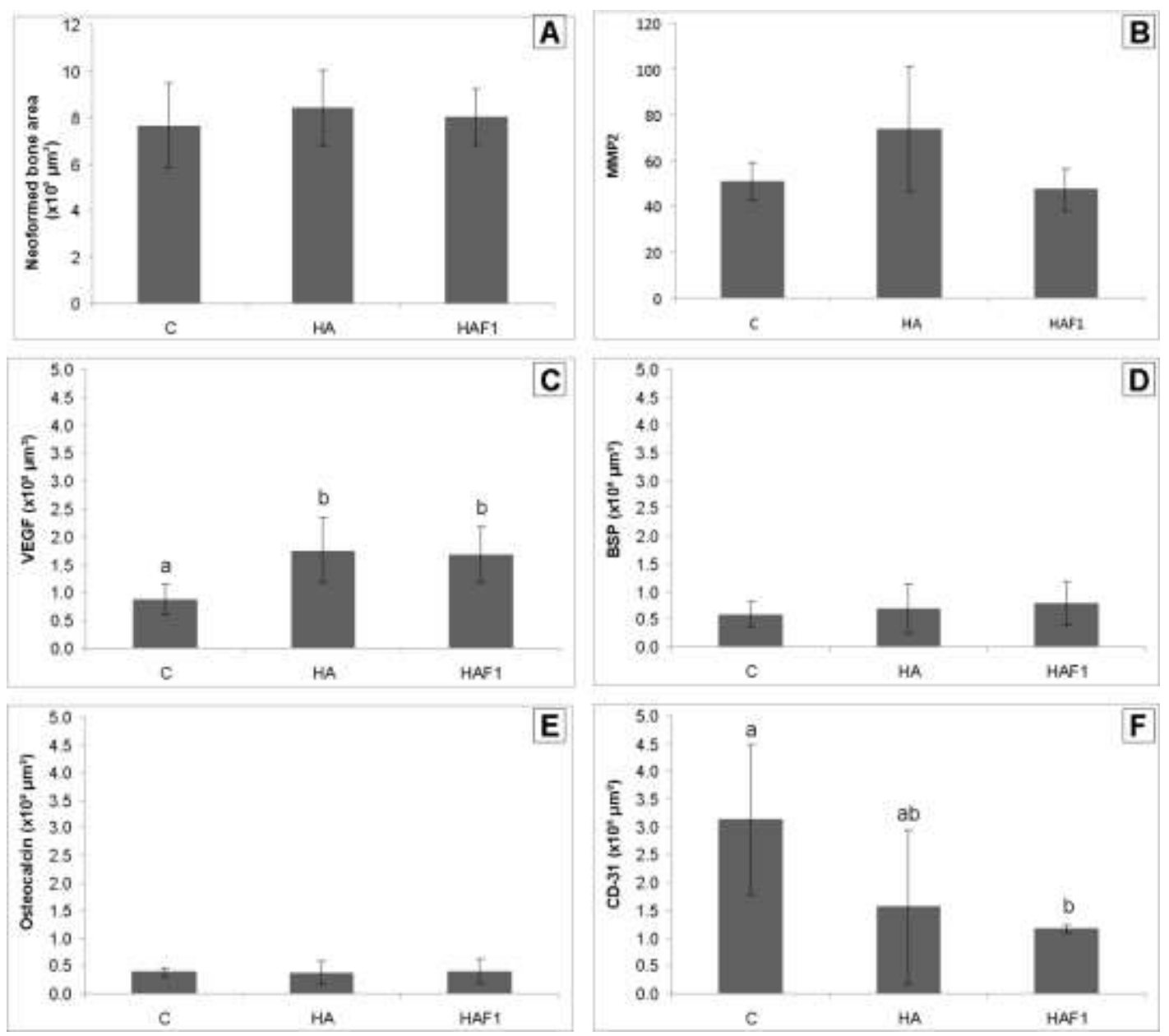

Figure 2. Bar chart of quantification of new bone formation $\left(10^{5} \mu \mathrm{m}^{2}\right)$; MMP2; VEGF $\left(10^{3} \mu \mathrm{m}^{2}\right)$; BSP $\left(10^{2}\right.$ $\left.\mu \mathrm{m}^{2}\right)$; Osteocalcin $\left(10^{2} \mu \mathrm{m}^{2}\right)$; CD-31 $\left(10^{3} \mu \mathrm{m}^{2}\right)$. 


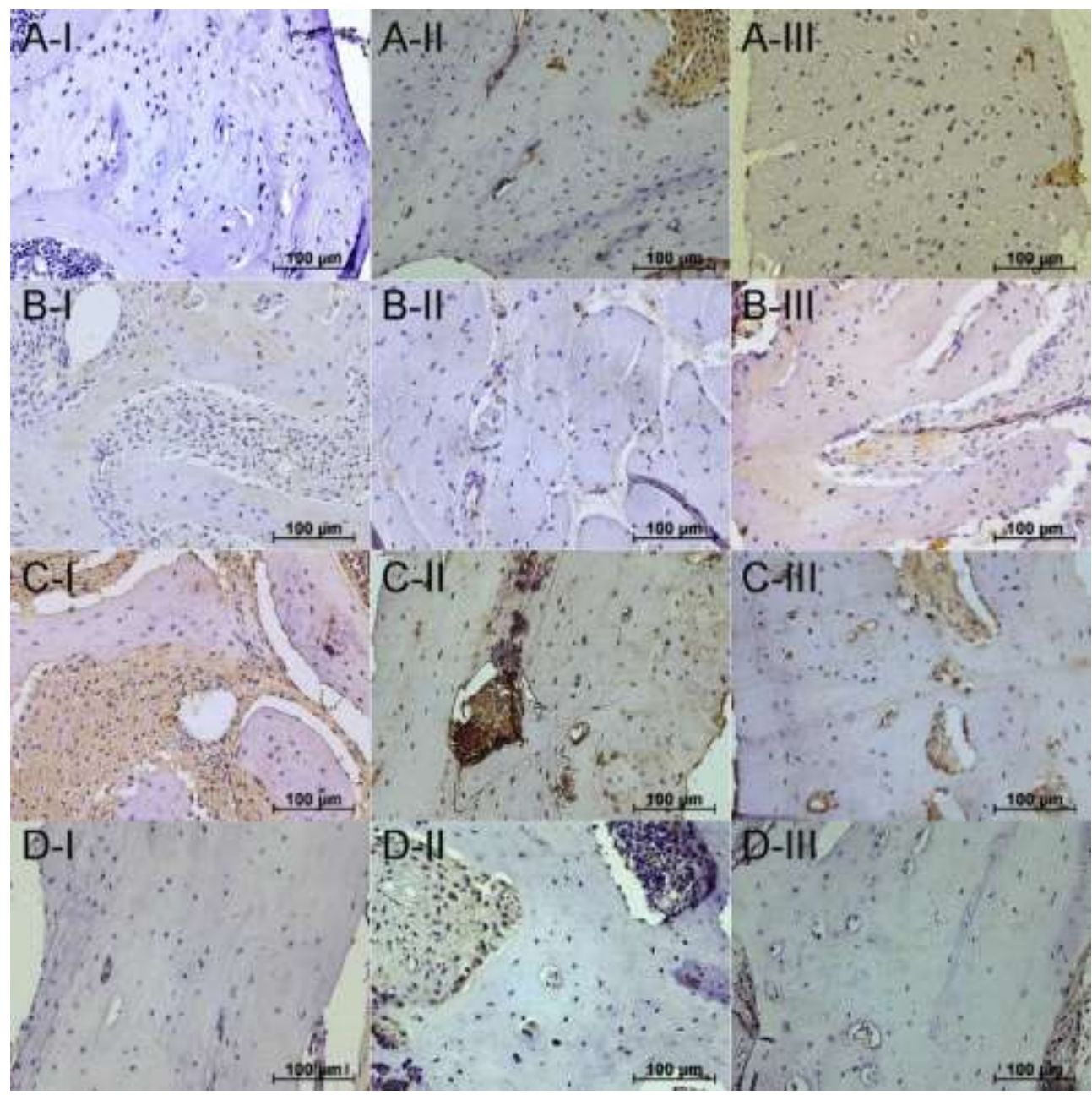

Figure 3. Immunostaining micrographs: VEGF: A-I Control, A-II HA and A-III HAF1; BSP: B-1 Control, B-II HA and B-III HAF1; Osteocalcin: C-I Control, C-II HA and C-III HAF1; CD-31: D-1 Control; D-II HA and D-III HAF1. (20x objective-microscopy lens).

\section{Discussion}

In the present study, the repair potential and the carrier matrix of $0.5 \%$ hyaluronic acid isolated and/or combined with the angiogenic fraction (F-1) of Hevea brasiliensis were evaluated. Hyaluronic acid is present in the extracellular matrix and found in the skin, cartilage, eyes and almost all structures of the body, thus used in several medical segments. Hevea brasiliensis, the rubber particles are mainly composed of cis-1,4-polyisoprene enrobed in a monolayer of protective phospholipid-protein membrane. The main composition of non-rubber particles are lutoids and Frey-Wyssling particles, whose roles are related to the latex biosynthesis, coagulation, and protective mechanisms(26).

The study of biomaterials with application to bone tissue repair has allowed the expansion of surgical rehabilitation techniques in both dentistry and medicine. In both situations, a biocompatible material is sought, with low cost and with sufficient therapeutic properties to justify its use. With the advancement of implant-supported rehabilitations, materials capable of promoting improvements in the bone repair process are frequently required, especially in situations where there is a need to use grafts to gain bone tissue volume. Aiming to repair mineralized tissue, we can find different materials that can act by osteopromotion, osteoinduction or osteoconduction. Traditionally, literature presents consecrated materials as the bone morphogenetic proteins (BMPs), especially BMP-2 and 7 that work by osteoinduction, promoting the differentiation of undifferentiated cells into osteoblast. Also, we can find, papers comparing the positive actions of BMP-2 and latex on the bone healing process or the association of this osteoinductive substance with bone grafts that had osteopromotive and osteoconductive properties and are used a lot at clinical and surgical practices $(3,4,27,28)$. The current research used the angiogenic fraction, portion 1, of latex aiming to stimulate the initial phase of the bone repair and hyaluronic acid as a carrier for this sustained delivery system. 
Native biological carriers may not maintain the same properties in vivo when used for drug administration as the combination may affect the physicochemical characteristics of the carrier(29). In vivo, the native form of HA is very soluble and rapidly metabolized. Given this, physicochemical modifications have been made. An example is crosslinking which has allowed the formation of gels that provide better resistance to degradation $(20,30)$. In addition, drugs associated with traditional HA hydrogels can be rapidly released due to relatively large pores. To prevent this from happening, different techniques of HA hydrogel production involving changes in chemical structure, pore size and degradation rate have been developed to provide functional tissue formation. Hybrid hydrogels with microgels or nanogels act as structural inputs and may provide better spatiotemporal release of active compounds capable of enhancing local cellular functions(20).

Several studies were performed aiming found the effect of HA on the healing of bone defects performed in different regions of body and using HA alone or combined with other substances or grafts. Cellular events such as mesenchymal cells differentiation, proliferation and migrations were observed study of Chang et al.(31). Aslan et al. used HA with bone graft in the created defect and they found fibrocartilage tissue and bone tissue formation after 40 days(32). Studies with HA alone showed different results. Studies reported that HA alone not promotes adequately enhance bone regeneration in critical-size defects, the use of combined forms of HA, such as BTCP appears to be a good vehicle to promote the bone healing when HA is used, when compared reticulated form and aqueous solution, the second showed better improvements $(31,33,34)$. When bone grafts are used in combination with HA, the results showed that HA alone and combined with bone grafts are capable to improve the bone healing(35). Zanchetta et al was founded that the combination of HA, chondroitin 6 sulphate and dermatan sulphate not presented notable improvements when compared with control group(36). When a $1 \%$ HA gel was associated with a collagen scaffold the results showed that this combination improves the new bone formation in critical-size defects(37).

Several cytokines are released during the cascade of the bone healing process, added to these mentioned before, we can find platelet-derived growth factors (PDGF) and their isoforms, transforming growth factor $\beta$ ( $\beta 1$ and $\beta 2$ ), vascular endothelial growth factor (VEGF), basic fibroblast growth factor (bFGF), epidermal growth factor (EGF), insulin-like growth factor (IGF), connective tissue growth factor (CTGF) and others factors(38). VEGF is relevant for bone formation, influencing vascularization and differentiation of bone and endothelial cells, and the absence of typically active forms of VEGF in bone formation may result in reduced initial calcification(39). In addition, VEGF increases bone fracture healing speed and bone neoformation area(40).

We studied some angiogenic and osteogenic factors that are currently presented in the healing process, MMP-2, BSP, osteocalcin, CD-31 and VEGF. Minor invasion of blood vessels in the defect region was observed in the HAF1 group since these group showed lower CD-31. Our results showed an increase in VEGF in the groups treated with HA and HAF1, indicating greater mitogenic activity of the endothelial cells when compared to the control. In addition, there was no significant difference for MMP-2, BSP, osteocalcin and neoformed bone area.

The selection of the animal for bone studies must consider the size of the fracture or defect, if this defect is critical or not (critical size implies a defect which will not heal spontaneously without any intervention), loading conditions of the cicatricial area, the age of animal representing the skeletal maturity, characteristics of the materials for posterior evaluation in this site, affordability, and ease of animal handling(41). In the present study, the Wistar male rat was used as an experimental animal model, having the advantages of easy allocation, ease of management, low cost and the possibility of collecting a sufficiently experimental sample from the statistical point of view. In the definition of an experimental model for the study of osteometabolic activities, it is necessary to take into account especially if these data will be representing the human population, thus 2 factors will act in this bone metabolism that are the activity of modeling and bone remodeling. Considering the transposition of the findings of this model to the human being, we must consider that in the skeleton of an adult human, bone formation is a result of local bone resorption and temporal bone formation, followed by the activation of the apposition process, this sequence being called bone remodeling and identified mainly by histomorphometric methods. In contrast to remodeling, modeling is bone formation and resorption at specific sites, and these 2 processes occur for long periods and independently of each other, with different histological characteristics as well(42). Many scientists have long considered that bone modeling activity predominated in the rat skeleton, which would compromise some studies involving 
osteometabolic diseases. However, it is currently considered a transition from modeling to remodeling that is related to age progression in both cortical and spongy bones(43).

Calvarial tissue was chosen in this particular model because it has several advantages for experimental studies in animals like the only mechanism of ossification by intramembranous way, easy access, low suffering for the animal, not much time for the surgical procedure, not much blood permitting to adapt the materials on the surgical area, easy to be removed after animal's sacrifice and others. So, during the last years, this bone has been used a lot to test bone replacement materials and bone regenerative therapies $(43,44)$, highlighting that this area makes the results more physiologically relevant than those data collected from bone induction in ectopic sites, such as muscle pockets or subcutaneous sites $(45,46)$.

Current research worked with bilateral surgical bone defects ( $6 \mathrm{~mm}$ of external diameter) on rat skull, which samples were destined for different methodologies explicit before. We are cautious and prefer to use the term "surgical" and not "critical" because the term "critical size defect" is sometimes arbitrarily defined and nowadays researchers are not using this term due to the clinical limitations. Each researcher defines the size of the bone defect, according to the limits of the interesting area and the representative clinical application. One factor that must be addressed in researches involving osteogenic materials is the spatial control of new bone formation that must be gradual and continuous, permitting to reestablish the anatomy of the scar area, without compromising the morphology and function of this considered area(47). Aiming to this, this particular in vivo study evaluates the capacity of hyaluronic acid to release the fraction one of latex protein. Particularly for the bone site chosen, the authors may consider that dura mater, preserved during the surgical access, plays an important role in the bone healing process of calvarial defects(48). According to studies found in the literature $(45,46,49)$, dura mater represents an abundant source of osteogenic cells and osteoinductive factors during calvarial wound healing. In this way, during experimental studies attention should be done about the surgical techniques to perform the bone defects, employing the trephine bur, it is possible to damage or also destroy the dura mater tissue, inhibiting this cicatricial process. Therefore, the type of recuperation of the surgical area of this particular bone may be affected by size of the defect, and also by how it was done.

It was chosen 4 weeks or 28 days for evaluation of the bone healing process. The repair process after a fracture or bony defect begins with the formation of granulation tissue by inflammation (1 to 7 days post-surgery), connective tissue that is organized over time ( 2 to 3 weeks post-surgery), immature and mature bone tissue associated to a phase of bone remodeling (months), and the angiogenic fraction of the latex used here would have a preponderant action in the initial phase of this repair that lasts up to the third week, so it is possible to test its action and of the hyaluronic acid carrier matrix. The spongy or trabecular bone has $70 \%$ of soft tissue formed mainly by bone marrow, and the compact or cortical bone has $95 \%$ of its composition formed by mineralized portions, exhibiting due to this, hardness much superior to the trabecular. Particularly, in the skull cap used here, the bone is deposited from the periphery to the center in an appositional manner.

Despite the influence on markers related to angiogenesis and the apparent tendency for greater trabeculation in the HA and HAF1 groups, there was no significant difference regarding the area of newly formed bone tissue in the analyzed period. Given the results obtained and the considerations presented, it is interesting to conduct new studies to verify bone repair in the presence of HA alone or combined with F1 over a longer period. In addition, other forms of analysis could be used to verify repair region characteristics and / or modifications to the gel to contribute to HA bioavailability.

The authors are grateful to Fapesp support (2019/03699-1), Miss Junia Ramos for technical support and Dr Joaquim Coutinho Netto for latex supply

The authors declare that they have no conflict of interest. 


\section{Resumo}

Este estudo avaliou o reparo ósseo em defeitos cirúrgicos de ratos tratados com ácido hialurônico $(\mathrm{AH})$ associado ou não à fração proteica de Hevea brasiliensis (F-1). Foram criados defeitos ósseos em 15 ratos albinos Wistar divididos em 3 grupos $(n=5)$ : Grupo controle (1) - coágulo sanguíneo; Grupo HA (2) - ácido hialurônico 0,5\%; Grupo HAF1 (3) - fração proteica F-1 0,1\% dissolvida em ácido hialurônico a $0,5 \%$. Após 4 semanas, os animais foram submetidos à eutanásia e o reparo ósseo avaliado por meio de análise histomorfométrica, zimografia e imunohistoquímica. A área óssea neoformada não apresentou diferença significativa $(\mathrm{p}=0,757)$, mas houve tendência de aumento da trabeculação óssea nos grupos HA e HAF1. Para a análise imunoistoquímica, houve diferença na marcação do fator de crescimento endotelial vascular (VEGF) $(p=0,023)$, sendo maior nos grupos HA e HAF1 do que no grupo controle. Nenhuma diferença significativa na sialoproteína óssea (BSP) (p = $0,681)$, osteocalcina $(\mathrm{p}=0,954)$, no entanto, diferenças significativas foram encontradas para a molécula de adesão de células endoteliais plaquetárias-1 (CD-31) ( $\mathrm{p}=0,040)$, com o grupo HAF1 sendo significativamente inferior ao controle. Para a análise zimográfica, não houve diferença significativa para metaloproteinase-2 (MMP-2) ( $\mathrm{p}=0,068)$, mas houve tendência de aumento da MMP-2 no grupo HA. Apesar da influência sobre os fatores angiogênicos e da aparente tendência de maior trabeculação nos grupos HA e HAF1, não houve diferença significativa na área de tecido ósseo neoformado no período analisado.

\section{References}

1. Peres JA, Lamano T. Strategies for stimulation of new bone formation: a critical review. Braz Dent J [Internet]. 2011;22(6):443-8. Available from: http://www.scielo.br/scielo.php?script=sci_arttext\&pid=S0103$64402011000600001 \& \operatorname{lng}=$ en \&tlng=en

2. dos S. Kotake B, Salzedas L, Ervolino E, Calzzani R, Sebald W, Issa J. Bone Recuperation After rhBMP-2 Insertion in Alcoholic Animals-Experimental Study. Curr Pharm Des [Internet]. 2015 Aug 10;21(24):3557-64. Available from: http://www.eurekaselect.com/openurl/content.php?genre=article\&issn=1381$6128 \&$ volume $=21 \&$ issue $=24 \&$ spage $=3557$

3. Issa JPM, Defino HLA, Netto JC, Volpon JB, Regalo SCH, Iyomasa MM, et al. Evaluation of rhBMP-2 and Natural Latex as Potential Osteogenic Proteins in Critical Size Defects by Histomorphometric Methods. Anat Rec Adv Integr Anat Evol Biol [Internet]. 2010 May;293(5):794801. Available from: http://doi.wiley.com/10.1002/ar.21097

4. Issa JP, Gonzaga M, Kotake BG, de Lucia C, Ervolino E, Iyomasa M. Bone repair of critical size defects treated with autogenic, allogenic, or xenogenic bone grafts alone or in combination with rhBMP2. Clin Oral Implants Res [Internet]. 2016 May;27(5):558-66. Available from: http://doi.wiley.com/10.1111/clr.12622

5. Sharmin F, O'Sullivan M, Malinowski S, Lieberman JR, Khan Y. Large scale segmental bone defect healing through the combined delivery of VEGF and BMP-2 from biofunctionalized cortical allografts. J Biomed Mater Res Part B Appl Biomater [Internet]. 2019 May 8;107(4):1002-10. Available from: https://onlinelibrary.wiley.com/doi/abs/10.1002/jbm.b.34193

6. Balabanian CAC., Coutinho-Netto J, Lamano-Carvalho TL, Lacerda SA, Brentegani LG. Biocompatibility of natural latex implanted into dental alveolus of rats. J Oral Sci [Internet]. 2006;48(4):201-5. Available from: http://joi.jlc.jst.go.jp/JST.JSTAGE/josnusd/48.201?from=CrossRef

7. Thomas MV, Puleo DA. Infection, Inflammation, and Bone Regeneration: a Paradoxical Relationship. J Dent Res [Internet]. 2011 Sep 19;90(9):1052-61. Available from: http://journals.sagepub.com/doi/10.1177/0022034510393967

8. Iyomasa MM, Mardegan Issa JP, de Queiróz Tavares ML, Lara Pereira YC, Sasso Stuani MB, Mishima F, et al. Influence of low-level laser associated with osteogenic proteins recombinant human BMP-2 and Hevea brasiliensis on bone repair in Wistar rats. Microsc Res Tech [Internet]. 2012 Feb;75(2):117-25. Available from: http://doi.wiley.com/10.1002/jemt.21033

9. Brandão ML, Reis PRM, Araújo LA de, Araújo ACV, Santos MH de AS, Miguel MP. Evaluation of wound healing treated with latex derived from rubber trees and Aloe Vera extract in rats. Acta Cir 
Bras [Internet]. 2016 Sep;31(9):570-7. Available from: http://www.scielo.br/scielo.php?script=sci_arttext\&pid=S0102-

$86502016000900570 \& \operatorname{lng}=$ en\&tlng=en

10. Muniz KL, Dias FJ, Coutinho-Netto J, Calzzani RAJ, Iyomasa MM, Sousa LG De, et al. Properties of the tibialis anterior muscle after treatment with laser therapy and natural latex protein following sciatic nerve crush. Muscle Nerve [Internet]. 2015 Nov;52(5):869-75. Available from: http://doi.wiley.com/10.1002/mus.24602

11. Penhavel MVC, Tavares VH, Carneiro FP, Sousa JB de. Effect of Hevea brasiliensis latex sap gel on healing of acute skin wounds induced on the back of rats. Rev Col Bras Cir [Internet]. 2016 Feb;43(1):48-53. Available from: http://www.scielo.br/scielo.php?script=sci_arttext\&pid=S0100$69912016000100048 \& \operatorname{lng}=\mathrm{en} \& \ln \mathrm{l}=\mathrm{en}$

12. Herculano RD, Silva CP, Ereno C, Guimaraes SAC, Kinoshita A, Graeff CF de O. Natural rubber latex used as drug delivery system in guided bone regeneration (GBR). Mater Res [Internet]. 2009 Jun;12(2):253-6. Available from: http://www.scielo.br/scielo.php?script=sci_arttext\&pid=S1516$14392009000200023 \& \operatorname{lng}=$ en\&tlng=en

13. Barreiros VCP, Dias FJ, Iyomasa MM, Coutinho-Netto J, de Sousa LG, Fazan VPS, et al. Morphological and morphometric analyses of crushed sciatic nerves after application of a purified protein from natural latex and hyaluronic acid hydrogel. Growth Factors [Internet]. 2014 Oct 26;32(5):164-70.

Available

from:

http://www.tandfonline.com/doi/full/10.3109/08977194.2014.952727

14. Friolani M, Daleck CR, Repetti CSF, Alessi AC. Use of rubber tree (Hevea brasiliensis) latex biomembrane in diaphragmatic injuries in rabbits - an experimental study. Brazilian J Vet Pathol. 2011;4(1):41-3.

15. Ferreira M, Mendonça RJ, Coutinho-Netto J, Mulato M. Angiogenic properties of natural rubber latex biomembranes and the serum fraction of Hevea brasiliensis. Brazilian J Phys [Internet]. 2009 Sep;39(3):564-9. Available

from: http://www.scielo.br/scielo.php?script=sci_arttext\&pid=S0103$97332009000500010 \& \operatorname{lng}=$ en\&nrm=iso\&tlng=en

16. Pinho ECCM de, Sousa SJ de F e, Schaud F, Lachat J-J, Coutinho-Netto J. Uso experimental da biomembrana de látex na reconstrução conjuntival. Arq Bras Oftalmol [Internet]. 2004 Feb;67(1):27_ 32. Available from: http://www.scielo.br/scielo.php?script=sci_arttext\&pid=S0004$27492004000100005 \& \operatorname{lng}=\mathrm{pt} \& n r m=\mathrm{iso} \& \operatorname{lng}=\mathrm{pt}$

17. Rosa S de SRF, Rosa MFF, Fonseca MAM, Luz GV da S, Avila CFD, Domínguez AGD, et al. Evidence in Practice of Tissue Healing with Latex Biomembrane: Integrative Review. J Diabetes Res [Internet]. $2019 \quad$ Mar 3;2019:1-17. Available from: https://www.hindawi.com/journals/jdr/2019/7457295/

18. Davi CP, Lombello CB, Ferreira M. Higher cellular interaction and faster production of natural rubber latex LbL films by spraying method. Int J Adv Manuf Technol [Internet]. 2019 Jan 2;100(14):999-1005. Available from: http://link.springer.com/10.1007/s00170-018-2778-z

19. McCarty MF. Glucosamine for wound healing. Med Hypotheses [Internet]. 1996 Oct;47(4):273-5. Available from: https://linkinghub.elsevier.com/retrieve/pii/S0306987796900663

20. Xu X, Jha AK, Harrington DA, Farach-Carson MC, Jia X. Hyaluronic acid-based hydrogels: from a natural polysaccharide to complex networks. Soft Matter [Internet]. 2012;8(12):3280. Available from: http://xlink.rsc.org/?DOI=c2sm06463d

21. Kilkenny C, Browne W, Cuthill IC, Emerson M, Altman DG. Animal research: Reporting in vivo experiments: The ARRIVE guidelines. Br J Pharmacol [Internet]. 2010 Aug;160(7):1577-9. Available from: http://doi.wiley.com/10.1111/j.1476-5381.2010.00872.x

22. Yamanaka JS, Yanagihara GR, Carlos BL, Ramos J, Brancaleon BB, Macedo AP, et al. A highfat diet can affect bone healing in growing rats. J Bone Miner Metab [Internet]. 2018 May 17;36(3):25563. Available from: http://link.springer.com/10.1007/s00774-017-0837-4

23. Faria PEP, Okamoto R, Bonilha-Neto RM, Xavier SP, Santos AC, Salata LA. Immunohistochemical, tomographic and histological study on onlay iliac grafts remodeling. Clin Oral Implants Res [Internet]. 2008 Apr;19(4):393-401. Available from: http://doi.wiley.com/10.1111/j.1600-0501.2007.01485.x

24. Marqueti R, Prestes J, Stotzer U, Paschoal M, Leite R, Perez S, et al. MMP-2, Jumping Exercise and Nandrolone in Skeletal Muscle. Int J Sports Med [Internet]. 2008 Jul;29(7):559-63. Available from: http://www.thieme-connect.de/DOI/DOI?10.1055/s-2007-989271 
25. Bradford M. A Rapid and Sensitive Method for the Quantitation of Microgram Quantities of Protein Utilizing the Principle of Protein-Dye Binding. Anal Biochem [Internet]. 1976 May 7;72(12):248-54. Available from: http://linkinghub.elsevier.com/retrieve/pii/S0003269776699996

26. Rippel MM, Leite CAP, Lee L-T, Galembeck F. Formation of calcium crystallites in dry natural rubber particles. J Colloid Interface Sci [Internet]. 2005 Aug;288(2):449-56. Available from: https://linkinghub.elsevier.com/retrieve/pii/S0021979705002742

27. Machado EG, Issa JPM, Figueiredo FAT de, Santos GR dos, Galdeano EA, Alves MC, et al. A new heterologous fibrin sealant as scaffold to recombinant human bone morphogenetic protein-2 (rhBMP-2) and natural latex proteins for the repair of tibial bone defects. Acta Histochem [Internet]. $2015 \quad$ Apr;117(3):288-96. https://linkinghub.elsevier.com/retrieve/pii/S0065128115000549 Available

from:

28. Siéssere S, de Sousa LG, Issa JPM, Iyomasa MM, Pitol DL, Barbosa APA, et al. Application of Low-Level Laser Irradiation (LLLI) and rhBMP-2 in Critical Bone Defect of Ovariectomized Rats: Histomorphometric Evaluation. Photomed Laser Surg [Internet]. 2011 Jul;29(7):453-8. Available from: https://www.liebertpub.com/doi/10.1089/pho.2010.2917

29. Zhang Y, Sun T, Jiang C. Biomacromolecules as carriers in drug delivery and tissue engineering. Acta Pharm Sin B [Internet]. 2018 Jan;8(1):34-50. Available from: https://linkinghub.elsevier.com/retrieve/pii/S2211383517302812

30. Zhao XB, Fraser JE, Alexander C, Lockett C, White BJ. Synthesis and characterization of a novel double crosslinked hyaluronan hydrogel. J Mater Sci Mater Med. 2002;13(1):11-6.

31. Chang Y-L, Lo Y-J, Feng S-W, Huang Y-C, Tsai H-Y, Lin C-T, et al. Bone Healing Improvements Using Hyaluronic Acid and Hydroxyapatite/Beta-Tricalcium Phosphate in Combination: An Animal Study. Biomed Res Int [Internet]. 2016;2016:1-8. Available from: https://www.hindawi.com/journals/bmri/2016/8301624/

32. Aslan M, Şimşek G, Dayi E. The Effect of Hyaluronic Acid-supplemented Bone Graft in Bone Healing: Experimental Study in Rabbits. J Biomater Appl [Internet]. 2006 Jan;20(3):209-20. Available from: http://journals.sagepub.com/doi/10.1177/0885328206051047

33. Aguado E, Pascaretti-Grizon F, Gaudin-Audrain C, Goyenvalle E, Chappard D. $\beta$-TCP granules mixed with reticulated hyaluronic acid induce an increase in bone apposition. Biomed Mater [Internet]. 2013 Dec 16;9(1):015001. Available from: https://iopscience.iop.org/article/10.1088/1748$6041 / 9 / 1 / 015001$

34. Diker N, Gulsever S, Koroglu T, Yilmaz Akcay E, Oguz Y. Effects of Hyaluronic Acid and Hydroxyapatite/Beta-tricalcium Phosphate in Combination on Bone Regeneration of a Critical-size Defect in an Experimental Model. J Craniofac Surg [Internet]. 2018 Jun;29(4):1087-93. Available from: http://journals.lww.com/00001665-201806000-00063

35. Koca C, Komerik N, Ozmen O. Comparison of efficiency of hyaluronic acid and/or bone grafts in healing of bone defects. Niger J Clin Pract [Internet]. 2019;22(6):754. Available from: http://www.njcponline.com/text.asp?2019/22/6/754/260029

36. Zanchetta P, Lagarde N, Uguen A, Marcorelles P. Mixture of hyaluronic acid, chondroitin 6 sulphate and dermatan sulphate used to completely regenerate bone in rat critical size defect model. J Cranio-Maxillofacial Surg [Internet]. 2012 Dec;40(8):783-7. Available from: https://linkinghub.elsevier.com/retrieve/pii/S1010518212000534

37. de Brito Bezerra B, Mendes Brazão MA, de Campos MLG, Casati MZ, Sallum EA, Sallum AW. Association of hyaluronic acid with a collagen scaffold may improve bone healing in critical-size bone defects. Clin Oral Implants Res [Internet]. 2012 Aug;23(8):938-42. Available from: http://doi.wiley.com/10.1111/j.1600-0501.2011.02234.x

38. Pietrzak WS, Eppley BL. Platelet Rich Plasma: Biology and New Technology. J Craniofac Surg [Internet]. 2005 Nov;16(6):1043-54. Available from: http://journals.lww.com/00001665-20051100000017

39. Maes C, Carmeliet P, Moermans K, Stockmans I, Smets N, Collen D, et al. Impaired angiogenesis and endochondral bone formation in mice lacking the vascular endothelial growth factor isoforms VEGF164 and VEGF188. Mech Dev [Internet]. 2002 Feb;111(1-2):61-73. Available from: https://linkinghub.elsevier.com/retrieve/pii/S0925477301006013

40. Li S, Yuan H, Pan J, Fan W, Zhu L, Yan Z, et al. The treatment of femoral neck fracture using VEGF-loaded nanographene coated internal fixation screws. Garcia Aznar JM, editor. PLoS One 
[Internet]. $2017 \quad$ Nov 8;12(11):e0187447. Available from: https://dx.plos.org/10.1371/journal.pone.0187447

41. Hunziker EB, Quinn TM, Häuselmann H-J. Quantitative structural organization of normal adult human articular cartilage. Osteoarthr Cartil [Internet]. 2002 Jul;10(7):564-72. Available from: https://linkinghub.elsevier.com/retrieve/pii/S1063458402908149

42. Carbonare LD, Micheletti V, Cosaro E, Valenti MT, Mottes M, Francia G, et al. Bone histomorphometry in acromegaly patients with fragility vertebral fractures. Pituitary [Internet]. 2018 Feb 6;21(1):56-64. Available from: http://link.springer.com/10.1007/s11102-017-0847-1

43. Dennison E, Cole Z, Cooper C. Diagnosis and epidemiology of osteoporosis. Curr Opin Rheumatol [Internet]. 2005 Jul;17(4):456-61. Available from: http://journals.lww.com/00002281200507000-00012

44. Hollinger JO, Kleinschmidt JC. The Critical Size Defect as an Experimental Model To Test Bone Repair Materials. J Craniofac Surg [Internet]. 1990 Jan;1(1):60-8. Available from: http://journals.lww.com/00001665-199001000-00011

45. Wang J, Glimcher MJ. Characterization of Matrix-Induced Osteogenesis in Rat Calvarial Bone Defects: I. Differences in the Cellular Response to Demineralized Bone Matrix Implanted in Calvarial Defects and in Subcutaneous Sites. Calcif Tissue Int [Internet]. 1999 Aug 1;65(2):156-65. Available from: http://link.springer.com/10.1007/s002239900676

46. Wang J, Glimcher MJ. Characterization of Matrix-Induced Osteogenesis in Rat Calvarial Bone Defects: II. Origins of Bone-Forming Cells. Calcif Tissue Int [Internet]. 1999 Dec 31;65(6):486-93. Available from: http://link.springer.com/10.1007/s002239900737

47. Mikos AG, Herring SW, Ochareon P, Elisseeff J, Lu HH, Kandel R, et al. Engineering Complex Tissues. Tissue Eng [Internet]. 2006 Dec;12(12):3307-39. Available from: https://www.liebertpub.com/doi/10.1089/ten.2006.12.3307

48. Greenwald JA, Mehrara BM, Spector JA, Fagenholz PJ, Longaker MT. Immature versus Mature Dura Mater: II. Differencial Expression of Genes Important to Calvarial Reossification. Plast Reconstrutive Surg. 2000;106(3):630-8.

49. Gosain AK, Santoro TD, Song L-S, Capel CC, Sudhakar P V., Matloub HS. Osteogenesis in Calvarial Defects: Contribution of the Dura, the Pericranium, and the Surrounding Bone in Adult versus Infant Animals. Plast Reconstr Surg [Internet]. 2003 Aug;112(2):515-27. Available from: http://journals.lww.com/00006534-200308000-00019 